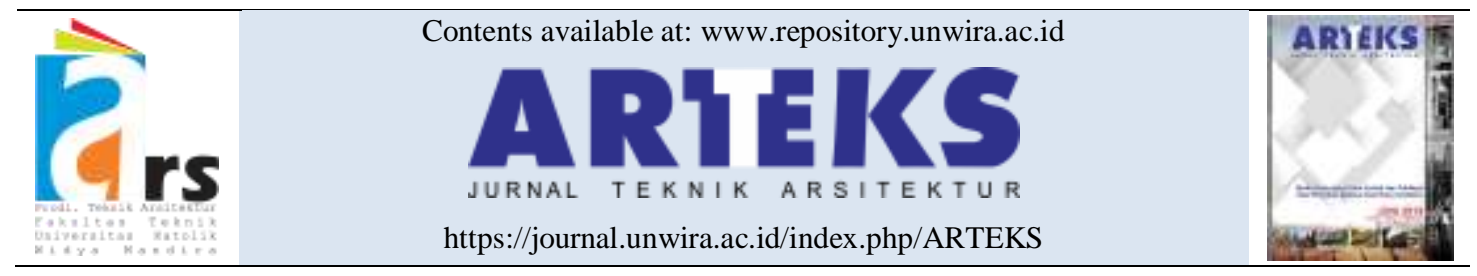

Research paper

doi: $10.30822 /$ arteks.v6i3.916

\title{
The importance of physical linkage and connectivity to integrate the kampung and formal parts of the city
}

Case studies: Hegarmanah and Ciumbuleuit sub-districts, Bandung, Indonesia

\section{Claudia Montenegro Vieira Santos ${ }^{1 \mathbb{D}}$, Yohanes Basuki Dwisusanto ${ }^{2 *}{ }^{*}$, Yohanes Karyadi Kusliansjah ${ }^{30}$}

${ }^{1}$ Architecture Study Program, Rua Machado, 59 Belo Horizonte, MG, Brazil

2, 3 Architecture Study Program, Faculty of Engineering,

Universitas Katolik Parahyangan, Indonesia

Jl. Ciumbuleuit no. 94, Hegarmanah, Bandung, Indonesia

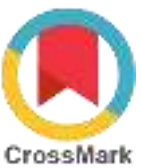

\begin{tabular}{|c|c|}
\hline ARTICLE INFO & ABSTRACT \\
\hline $\begin{array}{l}\text { Article history: } \\
\text { Received January 20, } 2021 \\
\text { Received in revised form March 10, } \\
2021 \\
\text { Accepted July 06, } 2021 \\
\text { Available online December 01, } 2021\end{array}$ & $\begin{array}{l}\text { This research investigates the critical role of physical linkage and } \\
\text { connectivity in the integration between formal and informal urban } \\
\text { areas of the city, as well as recognizes aspects related to physical } \\
\text { and social segregation that prevent this integration process. The } \\
\text { objective is to understand this role in relation to the viability of } \\
\text { integration. Qualitative method describes effectiveness of }\end{array}$ \\
\hline $\begin{array}{l}\text { *Corresponding author: Yohanes Basuki } \\
\text { Dwisusanto } \\
\text { Architecture Study Program, } \\
\text { Faculty of Engineering, } \\
\text { Universitas Katolik Parahyangan, Indonesia } \\
\text { Email: jbase@ unpar.ac.id } \\
\text { ORCID: https://orcid.org/0000-0003-2686- } \\
\text { 5048 }\end{array}$ & $\begin{array}{l}\text { connectivity and linkage thorough the complexity of interaction } \\
\text { between formal and informal areas in the built-form and open space. } \\
\text { This research includes two important areas in Bandung, Indonesia, } \\
\text { namely, Hegarmanah and Ciumbuleuit. Findings show Hegarmanah } \\
\text { as an enclosed configuration with more incidence of controlled } \\
\text { areas, through physical barriers, legal restrictions and circulation } \\
\text { limitations. Ciumbuleuit presents less controlled areas, encouraging } \\
\text { a wider use of public space, a variety of services, commerce, } \\
\text { commuting. Interaction between pedestrians and built environment } \\
\text { has experienced more adaptation, in a more open configuration. In } \\
\text { conclusion, space configuration, borders, limited access and forms } \\
\text { of control represent obstructions to the integration process, } \\
\text { impairing physical connectivity, encouraging spatial segregation } \\
\text { due to isolation and linkage disruption. Integration will be } \\
\text { stimulated when space is articulated and able to adapt. Coexistence } \\
\text { of seemingly social and physically segregated formal and informal } \\
\text { parts of the city can be comprehended when there is a correct } \\
\text { interpretation of the role of physical linkage and connectivity } \\
\text { through the analysis of space. }\end{array}$ \\
\hline
\end{tabular}

\section{Introduction}

The issue of physical linkage and connectivity is not a new subject in the problematic of space but in order to better comprehend it, integration and segregation will be critical to clarify how they occur, not only physically but also related to the social phenomenon. To integrate the site with its surroundings, it's first necessary to analyse existing points of access and linkage for both movement and infra-structure (Urban Design Alliance, Davies, and Baxter 2007) As we consider the importance of linkage and connectivity to the integration of formal and 
informal (kampung) areas of the city, physical segregation manifests as an empirical phenomenon of exclusion witnessed through borders, entrance gates in the urban kampungs, narrow and winding paths, extreme proximity between small informal houses. It is also revealed through the lack of communication between the planned and the spontaneous. Those will stand as issues related to spatial integration between formal parts and kampungs in the attempt to comprehend the important role of physical linkage and connectivity as a system to improve urban quality of life. As we consider that 'there are two types of city, the planned and spontaneous type of cities, we also need to remember that they often exist side by side' (Kostof and Tobias 2012), we aim to identify where people function together, and where groups diverge by consenting in separation of functions.

'Segregation may affect different social spheres in the way they connect and establish linkage' (Gehl 2011). It relates to quality of life as well as environmental and urban conditions that should be in harmony with the built environment. Spatially segregated areas are more vulnerable, where hierarchy of space is perceived and affects connectivity and integration due to fragmentation. In the social sphere, the negative impact of unequal living conditions can be a major problem as it affects development and is usually felt deeply among the less privileged, where configuration of space encourages exclusion.

Social, economic and environmental aspects will be closely intertwined but architecture is at the 'essence' of that (Widodo 2019; Sastrosasmito 2020). Form and Place will result from this connection, through interface relations and the identification of physical elements associated to the social and economic aspects coming to an Understanding level (Kusliansjah 2017; Mberu and Purbadi 2018).

The areas chosen for analysis, Hegarmanah and Ciumbuleuit are shown in figure 1 and are located in the north part of the city of Bandung, in the district of Cidadap. They are part of the city's tradition.

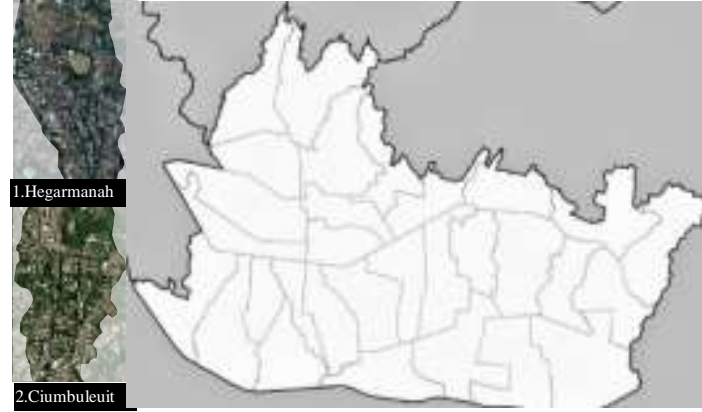

Figure 1. Map of Bandung and location in analysis Source: (Mandamaruta 2017)

Hegarmanah and Ciumbuleuit (figure 1) present challenges in common regarding accessibility and connectivity for pedestrians and vehicles. The dynamics in the relationship between built-form, open spaces and the human presence is affected by borders, boundaries and contour. Borders can influence how paths, streets and other structural elements in the city manifest and their role will be an important aspect to consider in this problematic. They relate to territory, being it geographical or political, and they represent restriction, control, or a delimitation of space. As communication in physical boundaries and borders happens through the dynamic between people and the built environment, it is subjected to linkage and connectivity and may experience disruption. Linkage and connectivity show that space and social life are connected (Hillier and Hanson 1984). They can promote or deter interaction, depending if separation and exclusion persist, or a sense of belonging is developed. Configuration, as subject to natural, physical, as well as social aspects, is crucial for an analysis between formal and spontaneous parts. Physical linkage in the kampung will reveal if there is integration to the city when, for example, roads can connect the area directly and the availability and relevance of services in those roads can determine if that kampung life is relevant to the city. The challenge is then to identify if integration can be encouraged in this setting, and represent a key aspect in the livability of such areas and its relation to the city. But cities have become more and more the place where phenomena of extreme poverty, social disadvantage and social segregation are concentrated, thru the growth of areas with social disadvantage (Critelli and Musella 2016).

An example of governmental initiative towards integration between formal and informal 
(kampung) areas took place in Brazil. Morro do Papagaio, as shown in figure 2, is a community embedded in one of the most expensive neighbourhoods in the city of Belo Horizonte, and has gained special attention from authorities as it has experienced accelerated growth and rapid increase of informal areas that affect the city. The area was formerly an 'island' surrounded by an arterial road (1), formal housing (2) and commerce in spotted areas (3).

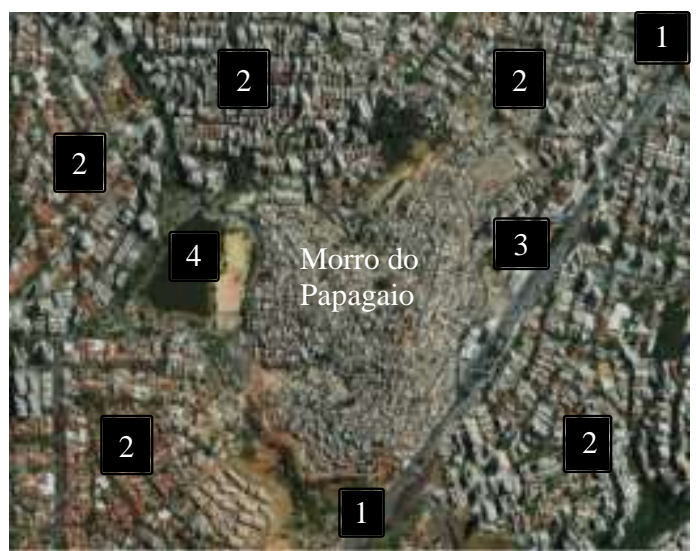

Figure 2. Aerial view: Morro do Papagaio Source: (Terra Incognita 2019)

In order to deal with high rates of criminality that were increasing in the area, the government decided to connect Morro do Papagaio to the medium and high-class residents around it by implementing a common space and improving access to the community. The construction of an ecological park and a water dam (4), shown on figure 3 , contributed to change the reality for both sides by improving social space and encouraging more interaction among distinct social groups, so inclusion of discriminated families became possible. New meaning and inclusion have helped the local community with a greater sense of belonging as well as awareness, despite the demands and challenges that will continue to rise as these are still distinct neighborhoods.

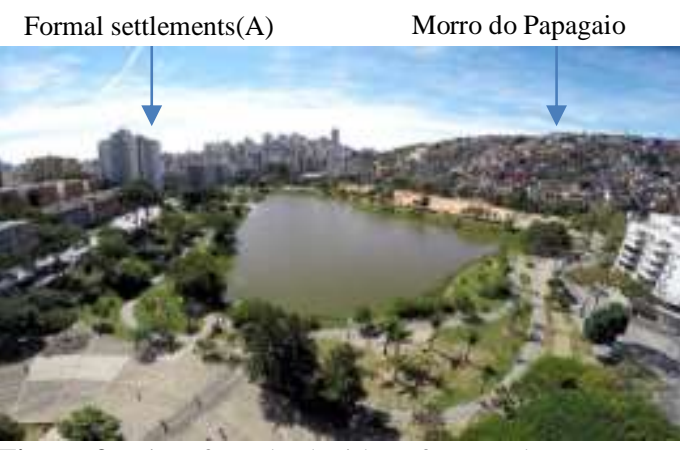

Figure 3. View from both sides of water dam Source: (Junior 2013)

\section{Method}

This research method is qualitative, which means that an investigation of the case studies will be made as to raise the phenomenon, with focus on the physical-spatial structure. Besides the main objects of study, a precedent case study will be added for analysis.

The qualitative method referred here is used to investigate, find, describe and explain the quality of spaces in the selected regions. It is processed in the form of sketches, pictures and maps. Effectiveness of connectivity and linkage will be verified in the complexity of the built environment and open spaces, and the interaction between formal and informal. Data will be analysed using a descriptive-comparative method. The comparative analysis is presented in the form of charts, so that relevant characteristics can stand out in contrast to those that will fade throughout the process. This descriptive analysis should describe how the phenomenon of linkage and connectivity is important for the integration between formal and informal areas.

\section{Result and discussion}

\section{Hegarmanah region}

Bandung is a global city in Indonesia, comprised of 30 districts and hundreds of subdistricts; among them, Hegarmanah, as in figure 4, in Cidadap district, which represents one of the areas of focus for this research. 


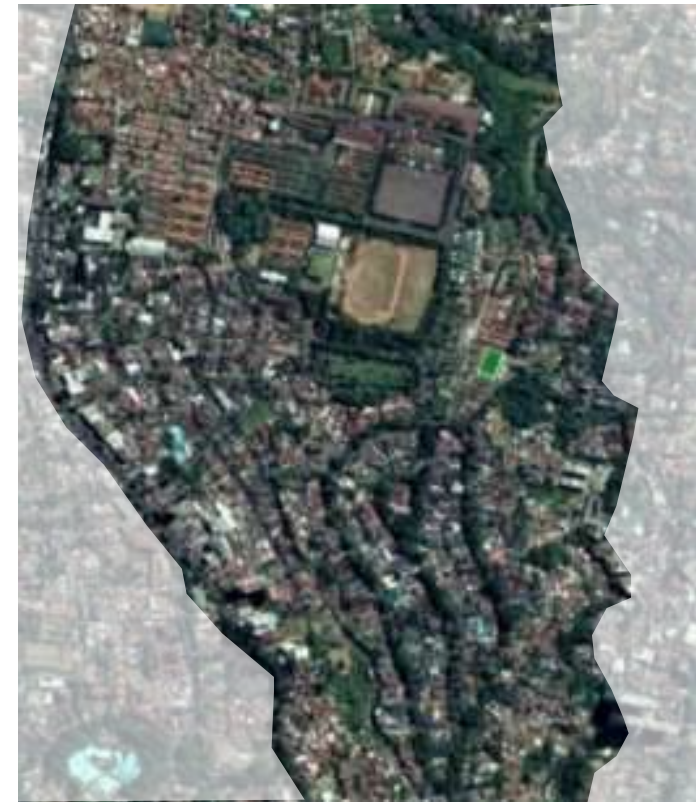

Figure 4. Map of selected Hegarmanah region

Space configuration in Hegarmanah was initially planned with balanced accessibility and road distribution, but because of the abrupt transformation due to rural diaspora to the city, rapid growth encouraged the beginning of informal settlements. Such changes have impacted connectivity and encouraged the phenomenon of physical segregation, through low accessibility and permeability, as well as the lack of infra-structure. Space configuration influences patterns of movement in space and its effects are on collection of individuals and how they interrelate through space (Hillier 1996).

The challenges in informal areas affect both pedestrians and vehicles. Open spaces have narrow, discontinued paths, with low connection, and extreme proximity between houses limits their use. A big city's economic growth does not benefit a good portion of migrants that usually have not much choice but to live in informal settlements, closer to the working place and that are affordable. But this also includes lower quality of life or privacy, socially disadvantage in terms of available resources, besides dealing with untreated waste and pollution on a daily basis.

The blending of former rural mindset into modern lifestyle not always happens in a smooth way, encouraging segregation through low interaction between kampung and formal houses. Spatially segregated areas experience hierarchy of roads, borders, forms of control, vulnerable space configuration, impacting connectivity through space fragmentation. Strategies of exclusion actually lead to social segregation and fragmentation (Carmona 2002). Fragmentation is also seen through the way form and function are implemented in the common space as the area is not accurately interpreted for the benefit of community. In Hegarmanah, private space is dominant over public, except the interface with the artery road that has the most concentration of commerce. Predominance of housing in Hegarmanah is formal and informal housing is basically near the edges or stifled by formal settlements as in figure 5 .

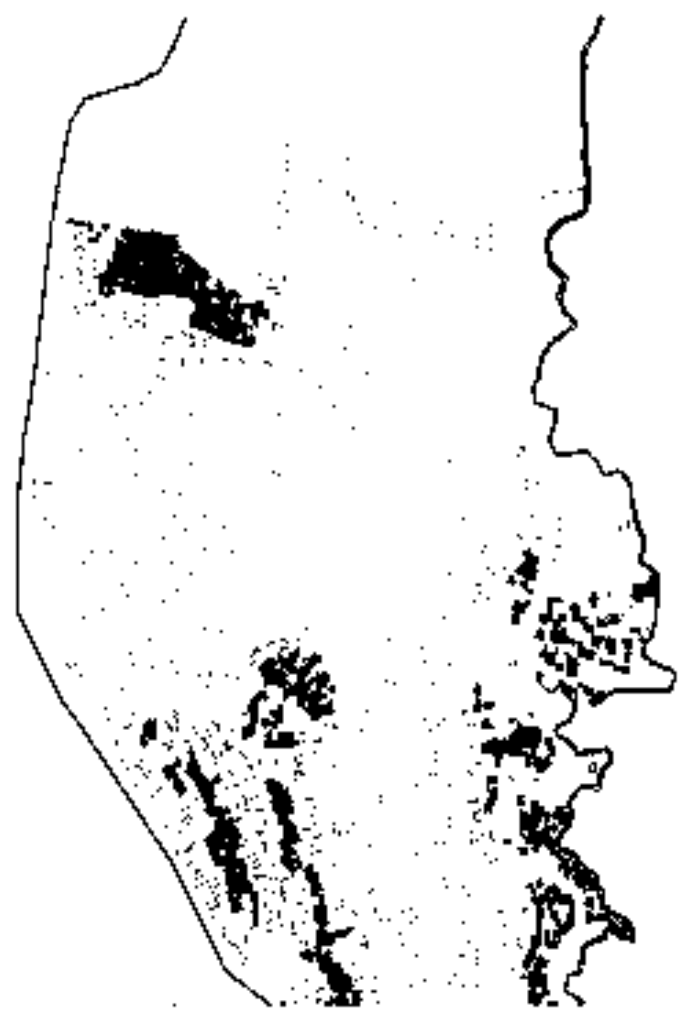

Figure 5. Map of segregated areas 


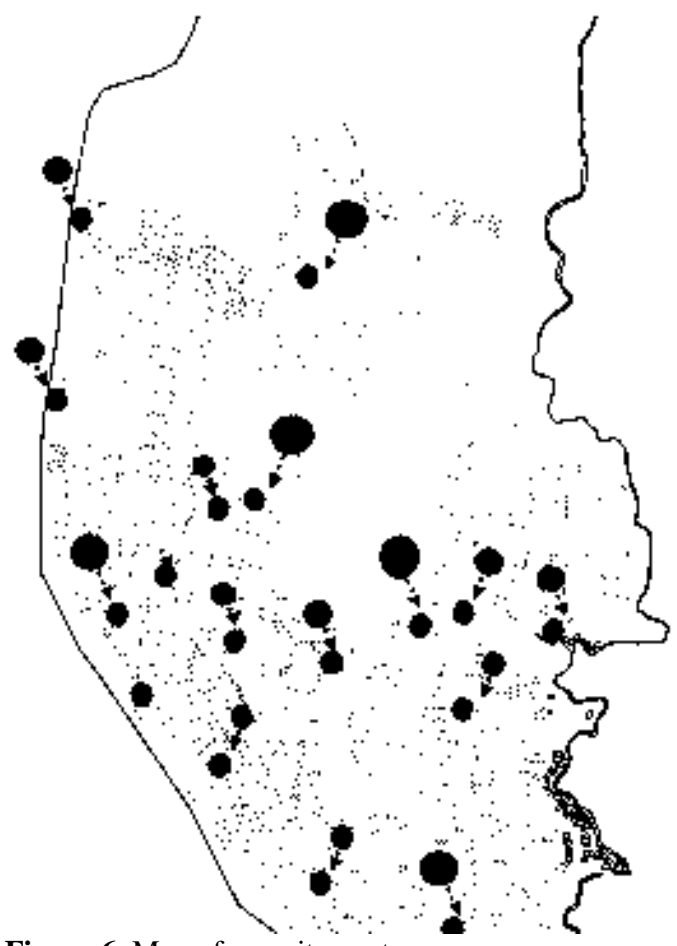

Figure 6. Map of security posts

The common characteristics in such kind of segregated areas are unsafe structure, extreme proximity of houses, challenging terrain and low permeability. One example of that is the gang behind the commercial area on Setiabudih road, shown in figure 7 , that represent a concentration of informal settlements blended in a pattern where open space actually became an extension of private space (Thomas 2002).

Another challenge is that most kampung are located in high-density areas where flooding and environmental degradation are difficult to avoid (Shirleyana, Hawken, and Sunindijo 2018).

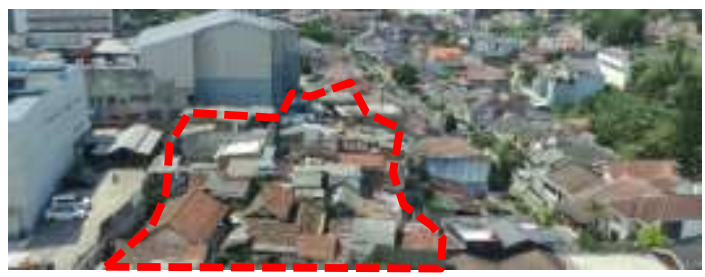

Figure 7. Informal settlements behind commerce

One form of control repeatedly seen that draws attention is the number of security posts, as shown in figure 6 . They are mostly legal, spread in different parts of this fairly small area. Reasons for that may be the number of private housing, scarce social life and SECAPA AD (Kharisma 2018).

Social values can be quality life regulators in a given society, and we should consider the negative or positive impacts, and identify how those will establish a connection with spatial configuration and influence social segregation.

A common phenomenon is the decreased social capital in urban communities, along with increasing individualism of urban society. The bigger the city, the more dominant individualism of its citizens and the thinner the community social capital (Sarosa 2020).

In a minor informal community, a friendly environment can still be found, there's trust and solidarity where one need the other, similar to what you would experience in a rural context. The community sphere still experiences strengthening (Dobbins 2009). But the bigger the city the more inequality stands out, as the social capital will get thinner by time. Though not all groups will experience that, this is a reality in informal areas in Hegarmanah, where privacy may be minimized by house proximity but interaction is increased.

Influencing factors related to linkage and connectivity in Hegarmanah

There are varied elements that influence the way a city is built. five elements in the city, for example, Edge, Sub-division, Buildings, Open and Public Space, Streets (Kostof 1991), represent a practical tool to a physical analysis of the urban space, as they facilitate a more accurate understanding of the area in question. Nevertheless, Edges and Streets elements, respectively, are the focus of this present research.

\section{Edges}

Cidadap river is the main natural edge in Hegarmanah, as in figure 8, margined by a valley. The river follows the north-south axis and the slope from the valley. Most parts of the terrain limit access, except for a narrow bridge, figure 9 , that connects to and from this closed valley. 


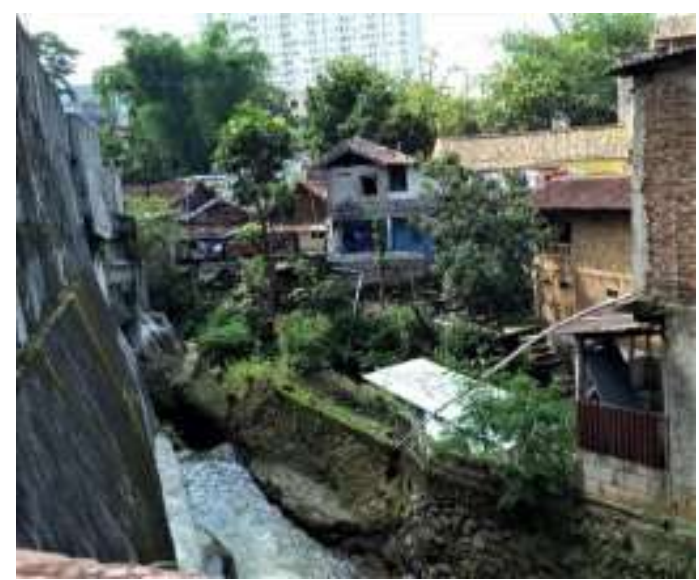

Figure 8. Cidadap river, between Hegarmanah and Ciumbuleuit sub-district

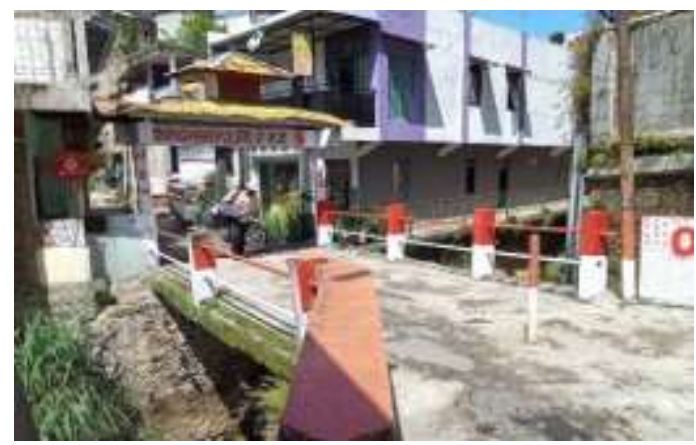

Figure 9. Border between Hegarmanah and Ciumbuleuit

Disruptions in linkage are present in informal settlements due to heterogeneous configuration, restricting circulation of vehicles, as shown in figure 10. Access to spontaneous areas is usually limited and, in most cases, just enough for motorcycles to get through by using the path initially destined for pedestrians.

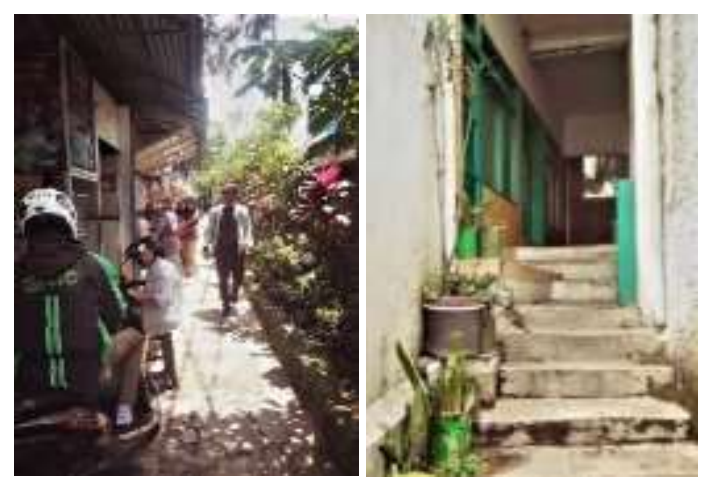

Figure 10. Pedestrian access to gang
Secapa AD, as seen on figure 11, embodies the main man-made edge in the area, through its gates, security and brick walls. Fences and walls from formal houses and the security posts (satpam) as in figure 12 are spread throughout the area and also function as a form of control. The territory in Hegarmanah is then considered mostly enclosed with low interaction between kampung and formal areas and physical hindrances. Though communication and language represent an important filter to understand the dynamics of bordering (Szary 2017), the lack of both inhibit social exchange and discourage interaction, and represent a social risk related to a loss of social interaction within kampung neighbourhoods (Shirleyana, Hawken, and Sunindijo 2018).

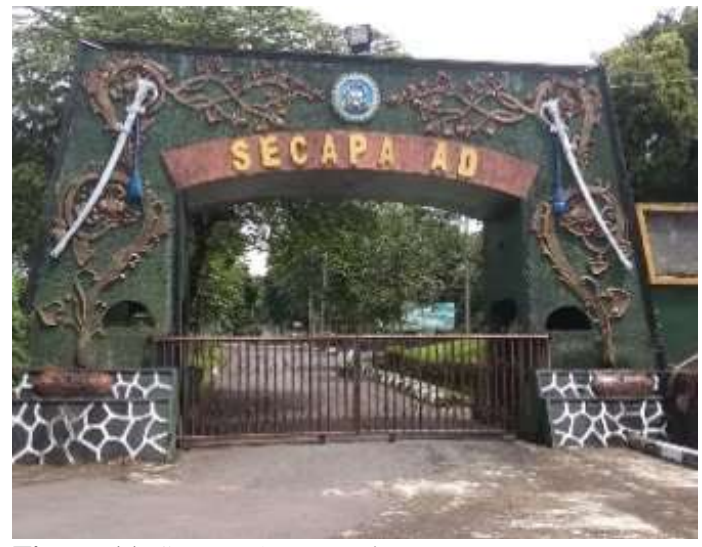

Figure 11. Secapa AD security post 


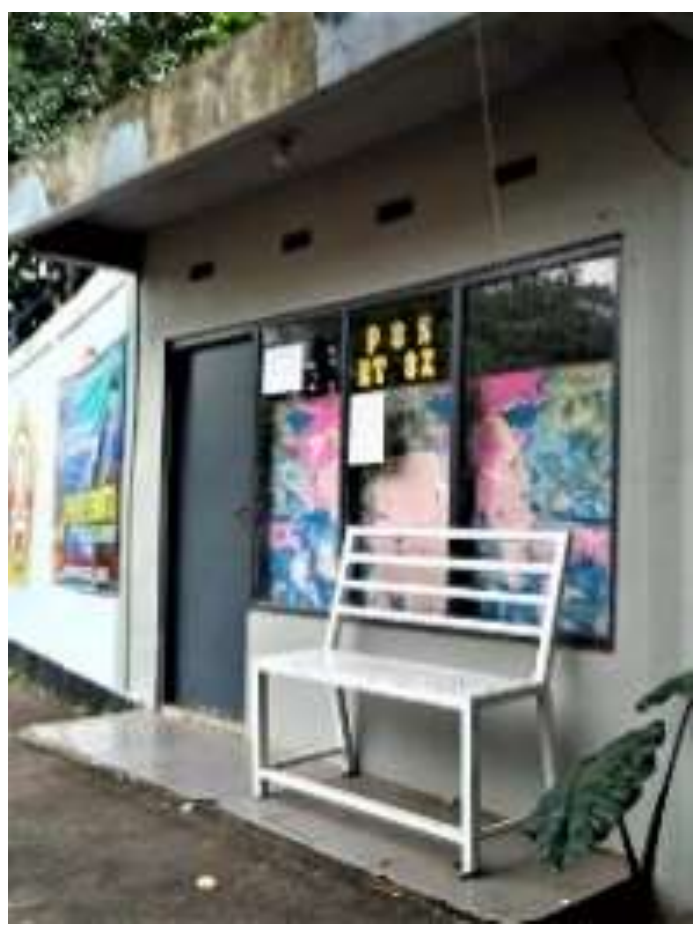

Figure 12. Security posts 'Satpam’

\section{Streets}

The formal roads have similar width in this area, with the exception of the tertiary roads that connect to gangs. Speed bumps, one-way roads and road hierarchy also represent forms of control (Habraken 1998). Since access to gangs is narrow, the communal space is limited and shared with passing-by pedestrians and motorbikes, as shown in figure 13. Still, proximity between informal houses impairs vehicle accessibility but allows interaction between immediate neighbours.

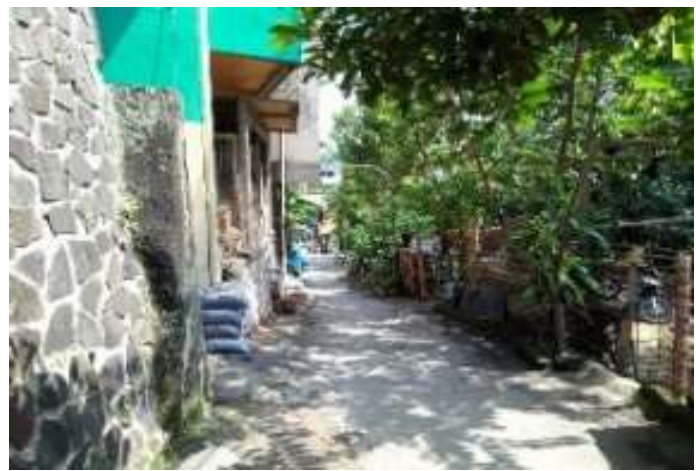

Figure 13. Informal motorbike access from jalan Hegarmanah to jalan Ciumbuleuit

The limitation regarding physical linkage makes the communal space an extension of the private space. Connectivity is resumed to a short radius in the gangs, but as it merges the formal roads, access is expanded. Road Hierarchy is not only manifested through its width, or physical features, but it is connected to vertical relations (Marshall 2004), defined by its importance, purpose and use.

\section{Ciumbuleuit region}

In the 60's, this quiet and traditional neighbourhood in the north part of Bandung, had large houses and was surrounded by front and back yards. But the scenario in Ciumbuleuit, figure 14, has changed and is no more considered environmentally friendly.

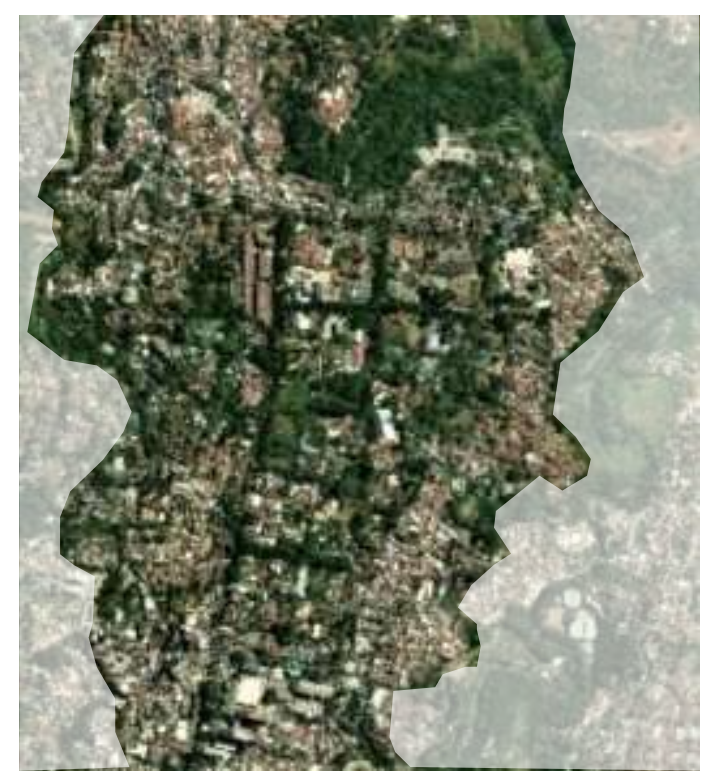

Figure 14. Map of Ciumbuleuit region in analysis

The space configuration was initially planned with balanced road distribution and accessibility, but abrupt transformation attracted the establishment of educational institutions, hospital and other uses, including informality due to the rapid growth caused by rural diaspora. Narrow roads were added informally, followed by traffic and pollution that now affect even the temperature of the area. Such changes, brought without proper structure and permeability have impacted connectivity and linkage, encouraging the phenomenon of physical segregation. Open spaces have narrow and discontinued paths in informal areas, and the extreme proximity between houses challenges vehicle circulation as well as pedestrian commuting. Fragmentation (Carmona 2002) is seen through the way form and 
function are implemented in the common space as the area is not accurately interpreted for the benefit of the community.

Planning high-density urban development may integrate kampung as a part of existing and new urban settlements to accommodate diverse populations (Shirleyana, Hawken, and Sunindijo 2018). Publicness of space is determined by the accessibility of the space and such provision is essential for any society (Patel 2016). But the blending of former rural mindset into modern lifestyle not always happens in a smooth way as there is low interaction between kampung and formal houses surrounding them.

The predominance of formal housing over informal settlements can be identified in this area, as in figure 15 , where the second concentrates at the edges but with less formal control, allowing both to experience changes.

Still, segregated areas are more vulnerable, which also applies in Ciumbuleuit where isolation is encouraged as they are comprised by a valley and a river. This also encourages space hierarchy and affects connectivity and integration, where temporary or long-term physical restrictions limits access.

'The duality of inside and outside adds a new dimension to the relation between social solidarity and space' (Hillier and Hanson 1984). What was observed in Ciumbuleuit is that when less control is imposed, as shown in figure 16, connection between distinct areas is increased, also encouraging walkability. "This promotion of walking is essential for sustainability of cities' (Delso et al. 2017). Social segregation can give way to more interaction between the natural and built- world, as well as the human relation with space. But elements that improve linkage in segregated areas are still scarce.

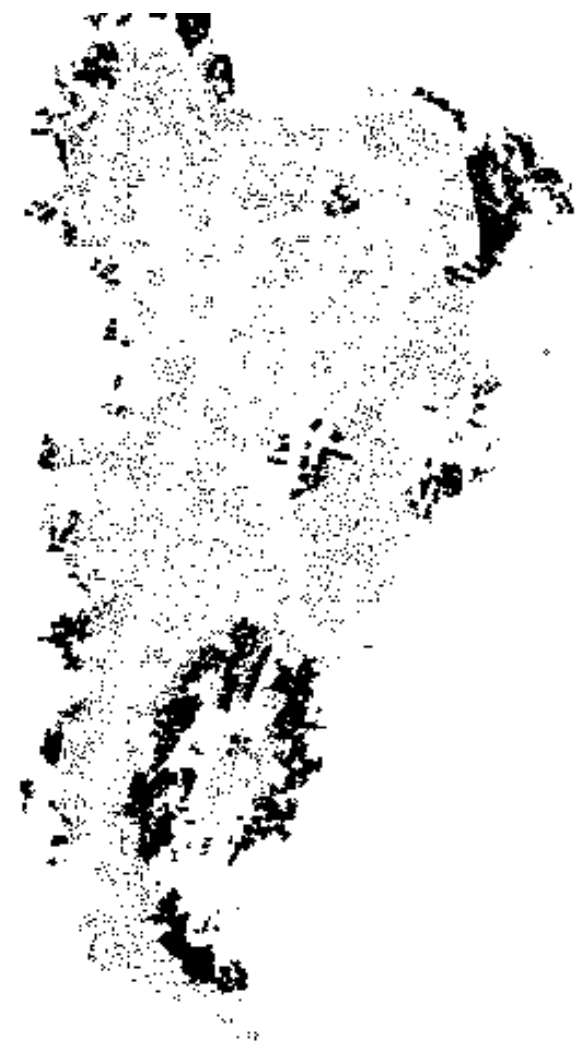

Figure 15. Map of segregated areas

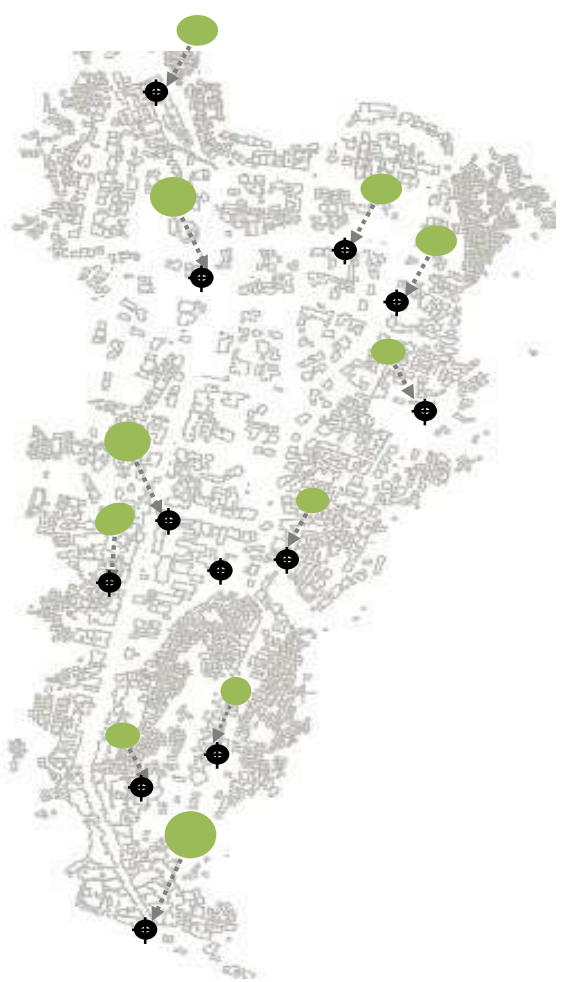

Figure 16. Map of security posts 
Influencing factors related to linkage and connectivity in Ciumbuleuit

\section{Edges}

Figure 17 shows that the manifestation of edges in Ciumbuleuit is both in the Natural and Man-made form. Cikapundung and Cidadap rivers along the valleys, compose the east and west natural edges respectively. They run from north to south, as they represent a border between Ciumbuleuit and Dago (East) and Hegarmanah and Ciumbuleuit (West).

Access is influenced by this north-south axis, as seen on figure 18 , also connecting to secondary roads via this converging point.

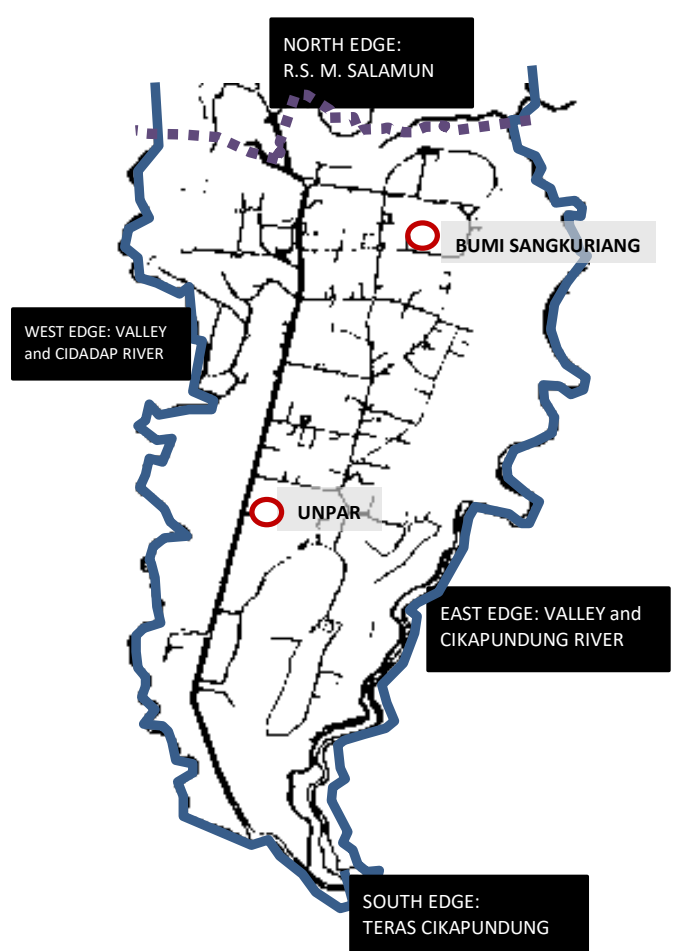

Figure 17. Ciumbuleuit borders

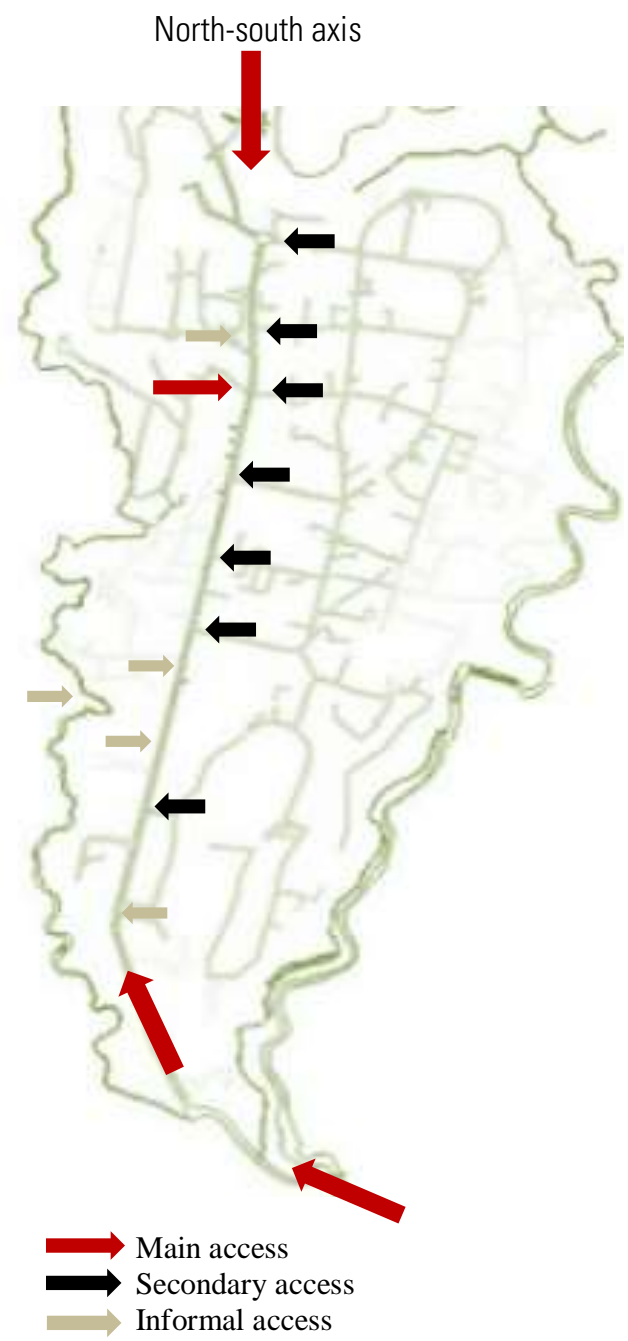

Figure 18. Ciumbuleuit access

Cidadap river is partially submerged by informal built-form as its size also decreases at the bottom of the hill. No legal crossing options are available in different portions of both borders, and the temporary solutions are usually risky and limited to pedestrians and motorbikes. Cikapundung river presents greater volume and visibility. As shown in figure 19, it has experienced government intervention for tourism purposes but still faces challenges related to its condition (Wijaya, Permana, and Swanto 2017). 


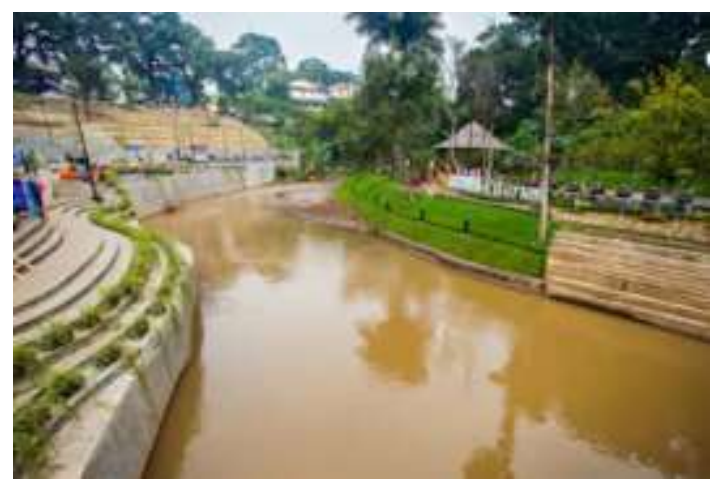

Figure 19. View of Teras Cikapundung

Source: (Pemerintah Daerah Provinsi Jawa Barat 2016)

Man-made Edges are represented by hospitals (R.S. M. Salamun and R.S. Rotinsulu), as well as educational institutions such as UNPAR, a Japanese school and governmental schools. Other existing edges include the entrance gates to the gangs, as seen in figure 20, that usually define the type and density of access allowed. Besides that, as you enter the informal areas, the distance between settlements will be visibly reduced showing low occurrence of edges, except for the door-to-door type.

The extreme proximity between informal houses affects accessibility of vehicles and also limits the use of public space toward socialization. Commuting happens from and to alleys on a necessity basis, where residents share the roads with those passing by. This leaves little room for social life, except between immediate neighbours.
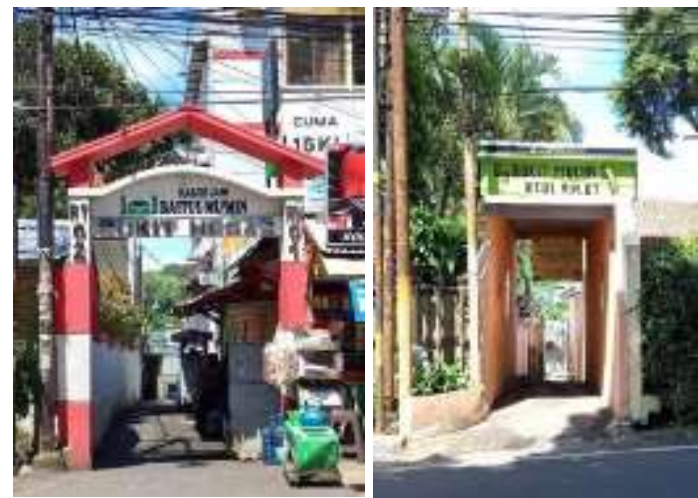

Figure 20. Ciumbuleuit Kampung access

\section{Streets}

Streets are elements defined by their function and relevance in a certain area. It can also reveal the level of social capital and the existence of hierarchy. The upper part of Ciumbuleuit road in figure 21, for example, reflects the surroundings, through the width and quality of that open space which comprises of formal, traditional settlements. So, although control is less intense in Ciumbuleuit, this hierarchy is defined on a relevance and importance basis.

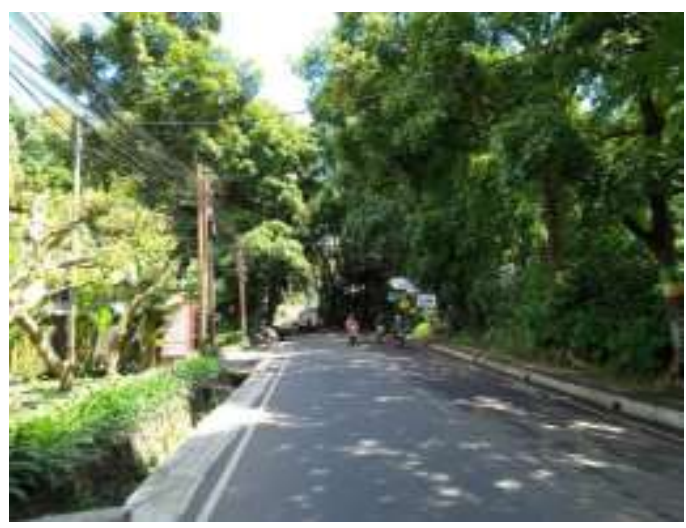

Figure 21. Upper part of Ciumbuleuit road

Ciumbuleuit street is the axis that links the north part of Bandung to Lembang, similarly to jalan Setiabudih in Hegarmanah. The dominance of commercial use is clearly concentrated along the lower parts of Ciumbuleuit street, as shown in figure 22 , representing the center or vein of that region. The predominant use is commercial, mostly with food stalls, supermarkets, restaurants and sports centres to attend the young public.

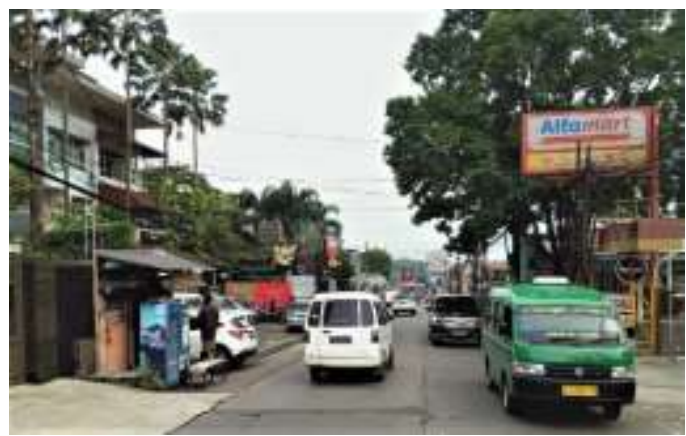

Figure 22. Lower Ciumbuleuit road

This is visibly connected to the impact of Parahyangan Catholic University as the center for higher education, naturally attracting a specific age group to the area. Hospitals also play an important role as they serve the local community in general and other areas of the city, impacting circulation and access that are intensified. Because of that some forms of control are imposed. Access to schools, hotels or governmental offices, for example, have physical 
edges and forms of control, represented by security posts and gates, but services and informal commerce are accessible, delimitated by small open spaces in the margins of other establishments.

Access from the main roads to the distributors have less control than Hegarmanah, allowing more circulation and developing more permeable connections, as in figure 23 but, as it reaches the informal sections, disruption takes place through the incidence of narrow alleys and sharing of space between pedestrians and motorbikes.

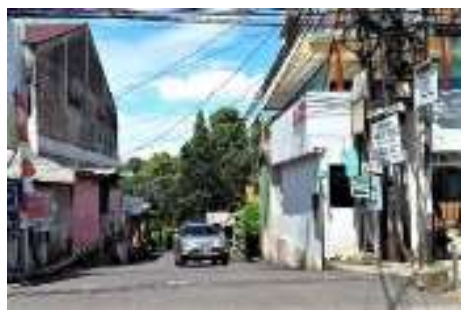

Figure 23. Road hierarchy

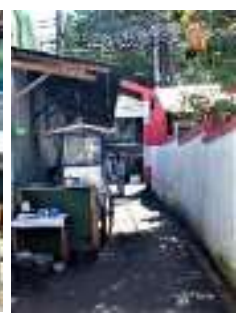

This can exemplify how hierarchy takes place through physical characteristics, like width or length, as well as through the dynamic of social interaction. Indeed, road hierarchy is not limited by width. The value attached to this common area defines the type of users and how such space is shared. Legible roads, despite their large dimensions for vehicles, are usually overwhelmed by the presence of pedestrians that are forced to share vehicles space due to narrow sidewalks. The secondary roads have even more scarcity of sidewalks and, besides the pedestrian, vehicles dispute space with street vendors. The inner parts of Ciumbuleuit features mostly locally used roads, since existing natural edges hinder crossing to the neighbouring region. Alleys used only by motorcycles and pedestrians offer a more enclosed atmosphere, as this physical restriction limits interaction on a larger scale. Figure 24 shows limitations in terms of circulation, as a car parks near the border of Hegarmanah and Ciumbuleuit, but only motorcycles are allowed to cross.

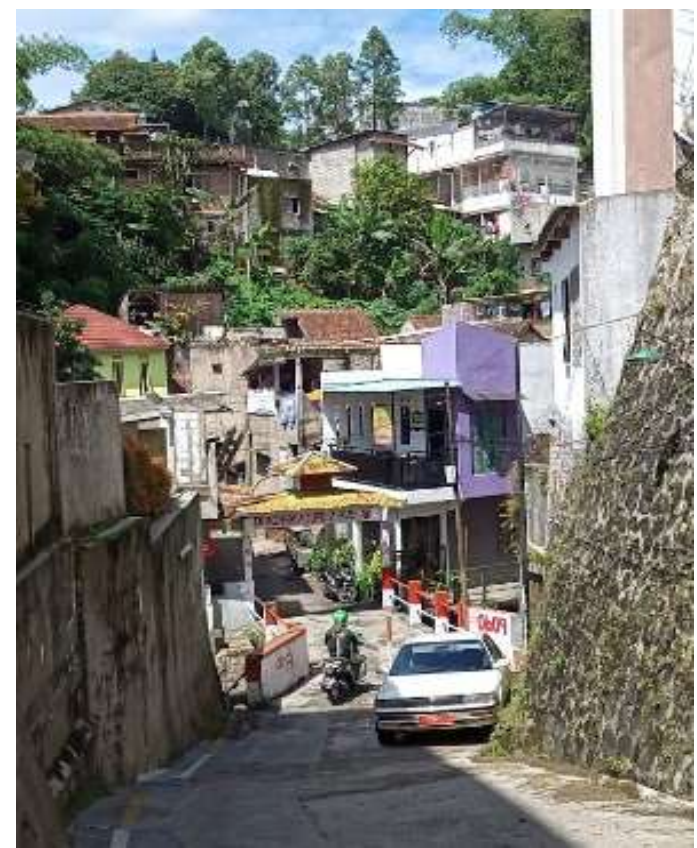

Figure 24. View from border between Hegarmanah and Ciumbuleuit

Challenges regarding physical and developmental changes then include narrowness of streets and lack of legible access but, on the other hand, they will most probably help to maintain a thicker social capital in the neighbourhood. Another issue is the lack of environmental awareness, as the behaviour from the local community has become an issue, especially regarding the disposing of wastewater and solid waste directly into the rivers.

\section{Conclusion}

Social segregation in Hegarmanah takes place not only because of economic status but also due to spatial configuration. Hegarmanah has more controlled areas, which increases restrictions for circulation of outsiders in the area, being more enclosed. The volume of security posts, one-way streets and distance between formal houses encourage isolation and individualism. One important phenomenon is the impact of Secapa AD. This huge block designed for education is not open for the public, focusing on a limited group of people. The location disrupts accessibility and discourages connectivity instead of being a point of attraction. Mid and upper mid groups affect the social capital of the area and roads around Secapa. Though the main struggle may not be lack of 
resources, there's a great need for relational exchange, so the value of the area can be maintained. Therefore, the territory in Hegarmanah can be considered mostly enclosed and contained, with low interaction between kampung (informal) and formal areas. Integration will manifest when there's space articulation and adaptability is a reality so, there's increasing interface between both social groups, the vulnerable and excluded areas and formal areas. This criterion can help the area to move from isolation toward integration.

Ciumbuleuit, on the other hand, has taken larger steps toward integration as adaptability to interventions has encouraged a stronger sense of belonging in the community. Less control is applied and there are more possibilities of linkage as it is more unrestrained, boosting social interaction, communication and livability, as observed in Ciumbuleuit Street and some secondary roads. This region also presents a wider variety of public services and commerce in comparison with Hegarmanah.

Though UNPAR represents a block, it is also the main educational institution in the area and its behaviour as an edge is more inclusive to different levels of social strata, since those who attend it have diverse background, budget and financial capacity to afford housing and basic daily needs. Permeability and accessibility are not impaired to the point of discouraging connectivity, but encourage movement and interaction to a certain level, also eventually attracting other uses to the area. The intensity of interactions between pedestrians, vehicles and the built environment shows more adaptation and encourages the area toward ownership with more open characteristics. Integration of various activities and functions in and around public spaces in Ciumbuleuit allow people to function together, stimulating and inspiring one another. The mixing of various functions and people makes it possible to interpret how the surrounding society is composed and the way it operates.

This research reveals that the coexistence of apparently social and physically segregated formal and kampung (informal) parts of the city can be comprehended when there is a correct interpretation of the role of physical linkage and connectivity through adaptation of space and social issues. The exchange between urban kampungs and the city has been jeopardized because of restrictions related to access and communication to the urban space and the built- environment, affecting the value of space. The built form, borders and other forms of control in both areas represent an obstruction to this integration process, as they isolate while impairing accessibility. Edges, street hierarchy, borders, circulation and permeability delimitate the level of connectivity and social interaction that can be established. The less permeable the neighbourhood, the greater the isolation and tendency for segregation, affecting beyond the physical sphere. This explains why Ciumbuleuit experiences more livability than Hegarmanah, where less control is applied, and there's more possibility of linkage. Physical segregation is not, then, a phenomenon restricted to vulnerable areas, but where low connectivity and exclusion are featured. And so, the need for a diverse group and social profile is made crucial for the life of a neighbourhood. They represent a guide towards the achievement of integration, in order to maintain social value, with higher levels of interaction and meaningful communication. Integration will only be encouraged if space is articulated between different social strata, encouraging their interaction, and adapting to the constant changes that physical linkage and connectivity experience through time. When both kampung and formal parts of the city struggle to experience good physical linkage and connectivity, variables like edges, streets, borders and forms of control are affecting them to the point integration is not possible. That means spatial segregation increases with the disruption of such elements, unless adaptation allows space articulation, bringing integration and segregation to a balance. The critical role of linkage and connectivity will then manifest turning integration between formal and kampung.

\section{References}

Carmona, Matthew. 2002. Public Places-Urban Spaces: The Dimensions of Urban Design. Boston, Berlin: MA : Architectural Press.

Critelli, Giuseppe, and Marco Musella. 2016. 'Social Segregation in Urban Area: The Results of a Project in the Metropolitan City of Reggio Calabria'. Procedia - Social and Behavioral Sciences 223 (June): 89-94. https://doi.org/10.1016/j.sbspro.2016.05.311.

Delso, Javier, Belén Martín, Emilio Ortega, and Isabel Otero. 2017. 'A Model for Assessing 
Pedestrian Corridors. Application to VitoriaGasteiz City (Spain)'. Sustainability 9 (3): 434. https://doi.org/10.3390/su9030434.

Dobbins, Michael. 2009. Urban Design and People. 1st ed. New Jersey: John Willey and Sons.

Gehl, Jan. 2011. Life Between Buildings -Using Public Space. Washington: Island Press.

Habraken, N. John. 1998. The Structure of the Ordinary, Form and Control in the Built Environment. Edited by Jonathan Teicher. Paperback. Cambridge: MIT Press.

Hillier, Bill. 1996. Space Is the Machine. Cambridge, England: Cambridge University Press.

Hillier, Bill, and Julienne Hanson. 1984. The Social Logic of Space. Cambridge: Cambridge University Press.

Junior, Alfredo Kalles. 2013. 'MORRO DO PAPAGAI'. Coluna Alfredo Junior. 2013.

Kharisma, Rifa. 2018. 'Usulan Bangunan Markas Komando Secapa AD Sebagai Bangunan Cagar Budaya Di Bandung'. Bandung.

Kostof, Spiro. 1991. The City Shaped: Urban Patterns and Meanings Throughout History. London: Thames \& Hudson, Ltd.

Kostof, Spiro, and Richard Tobias. 2012. 'The City Shaped: Urban Patterns and Meanings Through History'. Space. London: Bulfinch Press.

https://doi.org/10.1080/03612759.1992.9950 662.

Kusliansjah, Yohanes Karyadi. 2017. 'Related Aspects in the Intervention of Urban Space Framework'. Bandung.

Mandamaruta. 2017. 'Location Map of Bandung City, Indonesia'.

Marshall, Stephen. 2004. Streets and Patterns. London: Spoon Press, Taylor and Francis Group.

Mberu, Yuliana Bhara, and Yohanes Djarot Purbadi. 2018. 'Makna Ruang Jalan Di Kota Lama Kupang Menurut Pengguna Ruang Pedagang Informal Dan Formal'. ARTEKS: Jurnal Teknik Arsitektur 3 (1): 79-100. https://doi.org/10.30822/arteks.v3i1.56.

Patel, Shaurya. 2016. 'Ublic Spaces for All: How "Public" Are Public Spaces? Case of
Ahmedabad City's Riverfront Parks'. CEPT University.

Pemerintah Daerah Provinsi Jawa Barat. 2016. 'Di Tahun 2016, Program Teras Cikapundung Dilanjutkan'. Berita Jabar. 2016.

Sarosa, Wicaksono. 2020. Kota Untuk Semua: Hunian Yang Selaras Dengan Sustainable Development Goals Dan New Urban Agenda. Jakarta: Exposè.

Sastrosasmito, Sudaryono. 2020. 'Arsitektur Sebagai Realitas Kemanusiaan (Dari Keseharian Sampai Kesadaran Transendental)'. ARTEKS: Jurnal Teknik Arsitektur 5 (2): 141-42. https://doi.org/10.30822/arteks.v5i2.531.

Shirleyana, Shirleyana, Scott Hawken, and Riza Yosia Sunindijo. 2018. 'City of Kampung: Risk and Resilience in the Urban Communities of Surabaya, Indonesia'. International Journal of Building Pathology and Adaptation 36 (5): 543-68. https://doi.org/10.1108/IJBPA-02-2018-0025.

Szary, Anne-Laure Amilhat. 2017. 'Boundaries and Borders'. In The Wiley Blackwell Companion to Political Geography, edited by John A. Agnew, Virginie Mamadouh, Anna Secor, and Joanne Sharp, 1st ed., 568. United States: Wiley-Blackwell.

Terra Incognita. 2019. 'Morro Do Papagaio'. GIS. 2019.

https://gisenglish.geojamal.com/2019/08/dow nload-terra-incognita-v245-2019.html.

Thomas, Derek. 2002. Architecture and the Urban Environment: A Vision for the New Age. United States: Architectural Press.

Urban Design Alliance, Llewelyn Davies, and Alan Baxter. 2007. Urban Design Compendium. England, UK: English Partnerships.

Widodo, Johannes. 2019. 'Human, Nature, And Architecture'. ARTEKS: Jurnal Teknik Arsitektur 3 (2): 145-48. https://doi.org/10.30822/arteks.v3i2.65.

Wijaya, Karto, Asep Yudi Permana, and Noor Swanto. 2017. 'Kawasan Bantaran Sungai Cikapundung Sebagai Permukiman Masyarakat Berpenghasilan Rendah (MBR) Di Kota Bandung'. Jurnal Arsitektur ARCADE 11 (2): 57. https://doi.org/10.31848/arcade.v1i2.7. 


\section{Author(s) contribution}

Claudia Montenegro Vieira Santos contributed to the research concepts preparation, methodologies, investigations, data analysis, visualization, articles drafting and revisions.

Yohanes Basuki Dwisusanto contribute to the research concepts preparation and literature reviews, data analysis, of article drafts preparation and validation.

Yohanes Karyadi Kusliansjah contribute to methodology, supervision, and validation. 